the greater scheme conceived much earlier, aimed at an understanding of arthropod phylogeny. She had extended and completed a draft of the late $O$. W. Tiegs on The Evolution of the Arthropoda and had discovered that much basic information was just not available. In 1960 she retired from her Readership at Kings and from then on enjoyed the hospitality of the British Museum (Natural History) as Honorary Research Associate and was also a Research Fellow of Queen Mary College. Freed from teaching she felt able to seek the information for herself, beginning with a major examination of the structure and function of the mandible which was published in a wonderfully illustrated paper of over 200 pages between parts 7 and 8 of the locomotion series. She was becoming increasingly impressed by the mutual exclusiveness of the engineering designs between and even within classes. She considered these designs to have evolved in response to different habits which persisted for long periods and that each lineage represented an independent attainment of the arthropod grade of organisation.

About this time she was cruelly afflicted by an arthritic condition, yet she had enjoyed lunch-time tennis on the BM court until she was well over 60. At the Myriapod Congress in Manchester in 1972 she was relatively mobile because of an ingenious mechanical aid for one leg designed and constructed by herself and husband. Looking down a microscope at an exhibit, she drew for me an accurate picture of the cataract which limited her field to a narrow jagged annulus. Cataracts were removed one by one and hip and wrist joints were extensively re-modelled. During this difficult period she wrote The Arthropoda, recently published by Oxford University Press, a masterly summary of her 50 years research into their habits, functional morphology and evolution, running to 527 pages and lavishly illustrated by 186 text figures. She corrected the proofs in hospital after one of her operations. During the last two years she had compiled four chapters of a new general text on arthropods, written and presented a paper to a symposium on the evolution of the major arthropod groups at Hull, contributed a review to a book on arthropod phylogeny and undergone a second pelvic joint operation. The strain was too great.

The arthropods were not the only animals in her life. Her home and garden housed a veritable menagerie of birds and mammals which she cared for each day. Over a period of 21 years she developed the long haired Colourpoint cats with such delightful tem- peraments and exported kittens to all points of the globe. The history of her Mingchiu cats is recounted in her book Colourpoint, Longhair and Himalayan Cats (1971). This work ran parallel to her arthropod studies and brought her world-wide acclaim from an entirely different public. All this while at the centre of a delightful household, cooking superb meals, a delightful person with a lively conversation and an understanding smile. She will be sorely missed by her husband, Dr J. P. Harding and her two children, Elizabeth and Martyn.

J. Gordon Blower

\section{E. R. Creed}

Edwin Robert Creed died on 28 November 1978, aged 42, after an illness of three months. His parents were both physiologists, his father being a Fellow of New College, Oxford, also of Winchester. Robert was among that group of boys from Marlborough School who, from the 1920s onwards, became distinguished as biologists.

Like his father, he went to Trinity College, Oxford. After graduating in zoology he remained in the department to carry out research in ecological genetics. It gained for him the PhD Degree, also a Research Fellowship at New College. When this expired in 1970 under a time-limit, he became Lecturer, and later Senior Lecturer, in Zoology at University College, Cardiff, where he was in charge of genetics.

Unlike many scientists and scholars in general, Robert Creed did not find his period of National Service a disastrous waste of time. Among other things, it enabled him to develop his ability in engineering. Indeed, he retained what to some of us seemed an astonishing capacity to interchange and adjust the parts of old motor cars, of which he always had several. Moreover, for the rest of his life he took an active interest in the Territorial Army Volunteer Reserve.

His marriage to Elizabeth Hilton was a source of great happiness. He leaves two daughters, one aged 7 and the other 4 years. He liked to live in fairly large houses plentifully supplied with cats.

He was a good lecturer, but his outstanding educational achievement was as a demonstrator in practical classes. Here he excelled. He would take great care to arrange interesting exhibits and experiments. It was his habit to take away and work up the class results, and he would subsequently explain in what ways they had proved rewarding or unusual.
He was also a successful research worker. In order to investigate the ecological genetics of the butterfly Maniola jurtina he once camped with me on an uninhabited island in the Isles of Scilly, and he repeatedly joined our research group studying that insect in the south-west of England. He had a flair for such work, in which his observations were accurate and often revealing; and on these occasions his light-hearted energy was an asset and an encouragement.

His own researches were in particular directed to the polymorphism of the two-spot ladybeetle, Adalia bipunctata. This is typically scarlet with a black spot on each wing-cover; but two black forms with, respectively, four and six red spots are also known, all three types being controlled as multiple alleles. Creed showed that the black phases are industrial melanics, the only known instance of that condition in a species protected from predation by a powerfully unpleasant scent and taste: one practising, therefore, the aposematic way of life.

Creed and his colleagues also found that the black phases of $A$. bipunctata are favoured when pollution results from coal of high volatility, not of low volatility as in South Wales; nor does the presence of sulphur dioxide in the atmosphere encourage their spread, as in some moths. Moreover, the two black forms respectively survive better when the fuel is, or is not, subject strongly to caking. This work, described in his published articles, is a valuable contribution to our knowledge of adaptation to industrial conditions.

In spite of his youthful appearance, Robert Creed had a highly developed critical faculty and his comments when the draft of an article was submitted to him were of penetrating value. He was a Conservative in politics, original in research, devoted in friendship. His early death is a tragic loss of one who can ill be spared.

E. B. Ford

\section{Lord Cranbrook}

ThE death of John David, 4th Earl of Cranbrook on 22 November 1978 deprives many natural history and scientific societies of a skilful adviser and an enthusiastic and knowledgeable colleague.

His multifarious activities in public service and in support of East Anglian naturalists' organisations have been acclaimed elsewhere (The Times, 24 November 1978) but it is for his capacities as a scientist of no mean distinction and as a staunch member and officer of national biological societies that we, on behalf of the 